Article

\title{
Formalizing Objectives and Criteria for Urban Agriculture Sustainability with a Participatory Approach
}

\author{
Paola Clerino *(i) and Agnès Fargue-Lelièvre $\mathbb{D}$ \\ AgroParisTech-INRA UMR SAD-APT, 16 rue Claude Bernard, F-75231 Paris CEDEX 05, France; \\ agnes.lelievre@agroparistech.fr \\ * Correspondence: paola.clerino@agroparistech.fr; Tel.: +33-1-4408-1661
}

Received: 29 July 2020; Accepted: 9 September 2020; Published: 11 September 2020

check for updates

\begin{abstract}
The last few years have seen an exponential development of urban agriculture projects within global North countries, especially professional intra-urban farms which are professional forms of agriculture located within densely settled areas of city. Such projects aim to cope with the challenge of sustainable urban development and today the sustainability of the projects is questioned. To date, no set of criteria has been designed to specifically assess the environmental, social and economic sustainability of these farms at the farm scale. Our study aims to identify sustainability objectives and criteria applicable to professional intra-urban farms. It relies on a participatory approach involving various stakeholders of the French urban agriculture sector comprising an initial focus group, online surveys and interviews. We obtained a set of six objectives related to environmental impacts, link to the city, economic and ethical meaning, food and environmental education, consumer/producer connection and socio-territorial services. In addition, 21 criteria split between agro-environmental, socio-territorial and economic dimensions were identified to reach these objectives. Overall, agro-environmental and socio-territorial criteria were assessed as more important than economic criteria, whereas food production was not mentioned. Differences were identified between urban farmers and decision makers, highlighting that decision makers were more focused on projects' external sustainability. They also pay attention to the urban farmer agricultural background, suggesting that they rely on urban farmers to ensure the internal sustainability of the farm. Based on our results, indicators could be designed to measure the sustainability criteria identified, and to allow the sustainability assessment of intra-urban farms.
\end{abstract}

Keywords: urban farming; assessment; multicriteria; evaluation

\section{Introduction}

Urban agriculture is often described as supporting the economic, social and environmental sustainability of cities by providing local food, employment, educational functions or by participating in waste and water management [1]. In France, the recent exponential increase in urban agriculture [2] might be one way to ensure better urban resilience and sustainability.

Our study focuses on professional intra-urban agriculture (PIUA). Based on the typology of urban agriculture published by the Institute for Urban Planning and Development of the Île-de-France Region [3], we focus on PIUA farms including multifunctional microfarms, greenhouses and indoor systems, which are professional forms of agriculture located in urban areas. We exclude peri-urban farms, community gardens, and individual urban agriculture implemented in private gardens and balconies, as they are not located within urban areas and/or are not professional activities. If we consider Opitz's typology of urban agriculture [4], we focus on rooftops farms—zero acreage farming 
located on rooftops, and urban farms-providing social or environmental services in addition to food production. Both types are located within densely settled areas of city, which correspond to what we consider as intra-urban areas. The projects of PIUA farms are extremely diverse with a diversity of productions, of farming systems and economic models, from low-tech to high-tech projects, from associations to entrepreneurship, and from purely productive to social or pedagogical aims. In France, these projects are often supported by local authorities [5], their benefits for the city are admitted but the farm sustainability is questioned [6].

In the literature, sustainability assessment of PIUA farms often focuses on evaluating the impacts or benefits of urban agriculture [7-9] and seeks to identify or quantify the contribution of urban agriculture to sustainability, but does not include criteria to assess the sustainability of the farms themselves. Some studies only consider environmental and social dimensions through ecosystem services [10-14], or environmental and economic dimensions [15]. Numerous tools also exist to evaluate farm sustainability that were developed for rural and/or periurban farms [16-19]. However, these tools are not adapted to intra-urban farms as they do not include urban agriculture related issues (e.g., use of recycled materials from the city, involvement of volunteers in social exclusion situations, organization of training or conferences or pollution management for instance) [20]. The existing tools often include criteria and indicators not relevant or hardly measurable in PIUA farms (e.g., forage area-as cattle breeding is still rare in urban farms; nitrogen balance-as monitoring of organic input applied is rarely done, especially when it is produced on site). Moreover, many existing assessment tools are either not applicable at the farm level such as SAFA [21] which assesses agriculture value chains or Masc 2.0 [22] which assesses cropping systems, specific to one agricultural sector such as dairy farms for MOTIFS [16], or only focused on environmental sustainability such as INDIGO [23].

The criteria developed in the literature are therefore not adapted to assess the environmental, social, and economic sustainability of PIUA at the farm level. Based on these statements, we decided to develop sustainability criteria relevant at the farm level, designed specifically for professional intra-urban farms.

\section{Materials and Methods}

We focused on French PIUA in order to develop criteria suitable for the country's specific context but also suitable to represent the diversity of intra-urban farms implemented on the French territory [5]. To ensure that the sustainable objectives and criteria are representatives of the views of intra-urban agriculture stakeholders, we involved several categories of stakeholders during our study. The involved stakeholders were consulted during the whole process, making it a participatory approach.

The participants involved were selected to represent the diversity of French PIUA, including:

- Professional intra-urban farmers (heads of farms and employees, from different French cities);

- Decision makers (local authorities, land owners or PIUA funders spread across the country);

- Advisors to urban farmers (Chamber of Agriculture, young farmers' federation, professional network of urban farmers, consulting firms, researchers and lecturers in urban agriculture).

Consumers and beneficiaries of PIUA products and services are not directly involved in the design and implementation of PIUA farms, and were not included in the participatory process. However it could be interesting to study their own objectives and criteria for PIUA sustainability in order to compare the results with the ones we obtained for decision makers, urban farmers and advisors.

Our study was divided in four phases as described in Figure 1.

A focus group was held to outline a first draft of sustainable objectives and criteria, applicable to professional PIUA. The focus group involved different kind of PIUA experts: one consulting firm specialized in urban agriculture, two lecturers and two researchers working on urban agriculture related topics, a representative for a city council implementing urban agriculture projects for several years, and two experienced urban farmers. The diversity of background and strong experience of experts allowed exchanges about a wide range of concepts linked to PIUA sustainability. 


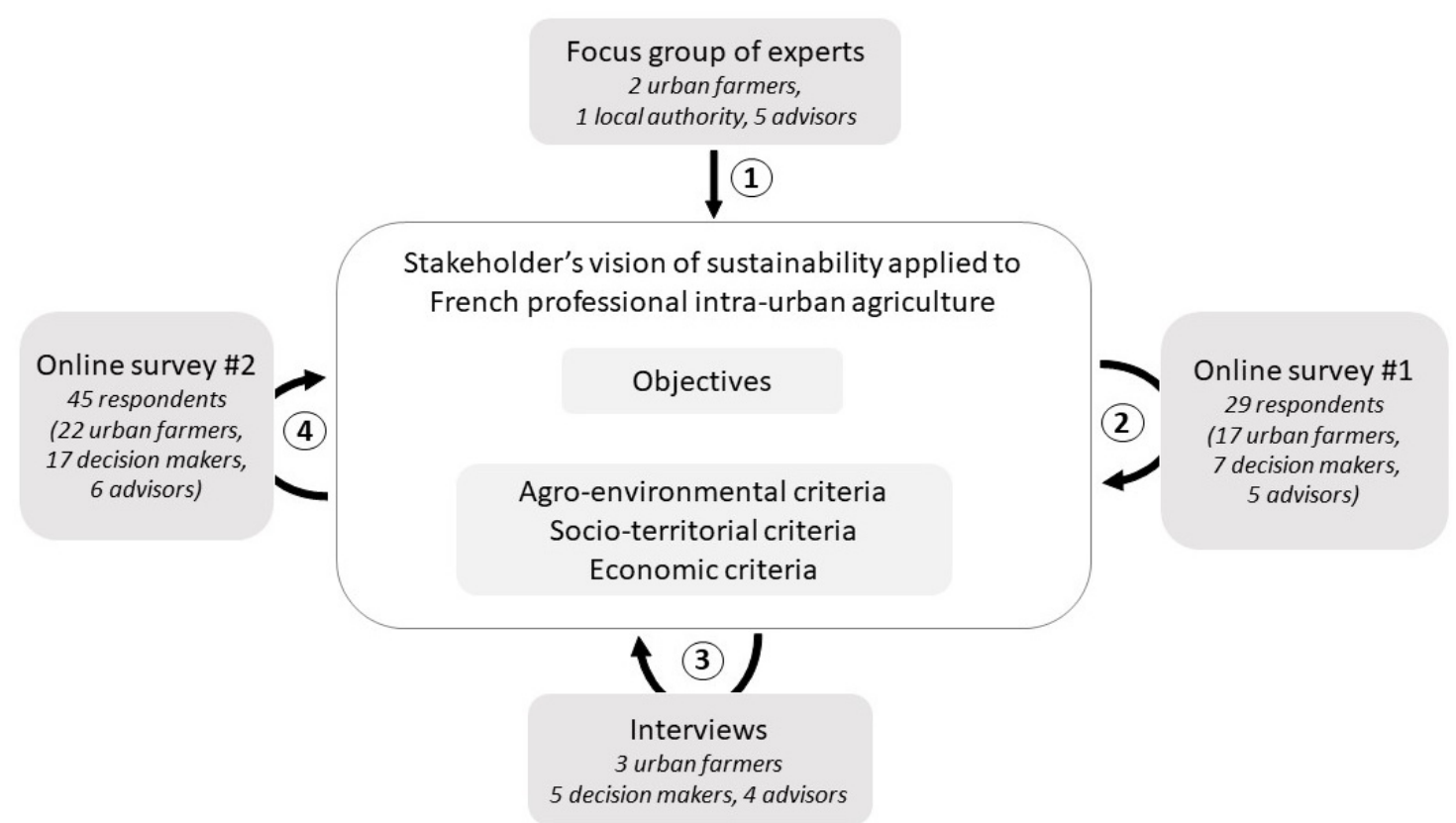

Figure 1. Participatory process to elaborate sustainability objectives and criteria for professional intra-urban agriculture.

The draft objectives and criteria were first submitted to a wider audience through an online survey, to assess if they seemed relevant to various stakeholders, and to collect comments or additional objectives and criteria. The form was sent by email to 44 contacts spread over the French territory, which were obtained during a general assembly of the French professional network of urban farmers (AFAUP). The answers were all anonymous. The respondents assessed the importance of each draft sustainability objective on a three level scale, comprising Useless, Secondary, and Important options. Then, they assessed the draft sustainability criteria on a Likert scale from 1 to 5,1 meaning that they consider the criterion as useless, and 5 as very important. In addition, respondents were asked if they had additional objectives and criteria to suggest, and if they had specific remarks regarding the ones suggested in the survey. We obtained 29 answers, as detailed in Figure 1. The answer rate for this first online survey was $66 \%$, which is satisfactory. The sample may seem limited, however, considering the small size of the French PIUA sector, it is still relevant: indeed, the AFAUP counts 80 members [24], including urban farmers and advisors, and the French local authorities association drew up a list of 30 local authorities implementing urban agriculture projects in France [5].

Then, interviews were conducted with several stakeholders in order to gather qualitative data to complement the quantitative data obtained through the first online survey. During the interviews, we presented the draft objectives and criteria to gather stakeholders' feedback and pin down their potential use of such sustainability criteria. We carried out 12 semi-structured interviews as detailed in Figure 1. During the interviews, the draft objectives and criteria were discussed in detail, taking into account the needs and concerns expressed by the stakeholders, and the diversity of their opinions regarding the sustainability of PIUA. Criteria were explained when not perceived as clear, and reformulations were suggested until interviewees considered them satisfactory.

Based on the results of the first online survey and the interviews, the sustainability objectives and criteria were reformulated by the authors, which mostly consisted of rewording. Some criteria were also added, moved from one sustainability dimension to another, or merged. The edited objectives and criteria obtained were submitted to stakeholders through a second online survey. The form was sent to 93 people, including the listing of stakeholders contacted during the first online survey and additional people, identified thanks to the interviews (people interviewed but also some of their contacts working in PIUA). In addition, people contacted were encouraged to disseminate the survey to their own 
network (through an opened web link), so the total number of people reached might be higher than the initial 93 people contacted. The second online survey followed the same protocol as the first online survey. An additional section was included within the questionnaire compared to the first survey, asking the respondents to evaluate their need for sustainability criteria, and to detail their potential use. This survey obtained 45 answers, with an answer rate around $48 \%$.

Some stakeholders participated in several steps: initial focus group, online surveys, and/or interviews. It is not possible to assess how many stakeholders participated to online surveys and other steps of the process as the answers to online surveys were all anonymous. However, the stakeholders who participated in the focus group, and the stakeholders interviewed, were representing different structures.

\section{Results}

Results are presented in three parts, the first one focusing on the potential use and users of sustainability assessment criteria for intra urban farms, the second one presenting the sustainability objectives of PIUA obtained, and the third one the sustainability criteria.

Part of the work relied on finding the exact wording expressing a comprehensive view of sustainable PIUA. This work was done in French, and the translation to English may imply a loss of its specificity, even if the authors worked with English speakers to ensure the most accurate translation in this article. The French version of the sustainability objectives and criteria are presented in Appendix A.

\subsection{Potential Use and Users of Sustainability Criteria for Intra-Urban Farms}

During the interviews, urban farmers indicated that criteria to assess the sustainability of urban farms would hardly be directly used by them or by other urban farmers, because of a lack of time and incentives. On the other hand, interviewed decision makers insisted on their need for sustainability criteria designed for PIUA, as they currently have no formal framework to assess the urban farms they are supporting or want to support.

During the second online survey $55 \%$ of the urban farmers and $83 \%$ of the decision makers and advisors declared that the assessment criteria would be very useful for them. Amongst the potential uses declared by decision makers and advisors, the most mentioned were: analysis of answers to call for proposals, monitoring of existing projects and support to the implementation of new projects. Answers were similar between advisors and decision makers, except for the support to implementation of new projects, which was more often mentioned by advisors than by decision makers, as one of the core missions of advisors is to support farmers in designing their project.

The results suggest that decision makers and advisors are more interested than urban farmers in a set of criteria to assess PIUA farms sustainability; however even if the criteria are mostly claimed by decision makers, urban farmers might have to use them if they collaborate with decision makers, or answer to a call for proposal. Therefore, urban farmers' involvement in criteria design is important to strengthen their legitimacy.

\subsection{Sustainability Objectives}

Sustainability objectives were first drafted during the experts' focus group, and then submitted to a wider audience through the first online survey. Based on respondents' feedbacks and interviews, three out of seven objectives were modified. Table 1 presents the reformulated objectives according to these feedbacks.

Two objectives drafted as Maximize socio-territorial services: re-appropriation of space and Maximize socio-territorial services: landscape services were merged to obtain objective six: the need to distinguish the concepts of re-appropriation of space and landscape services was not as clear for stakeholders as it was for the group of experts. Objective 3, initially drafted as Have economic meaning, was also modified by adding ethical meaning. This suggests that for PIUA, stakeholders' economic goals cannot be reached without considering the ethical concerns. 
Table 1. Sustainability objectives of professional intra-urban agriculture (PIUA) defined by French stakeholders.

\begin{tabular}{cc}
\hline $\begin{array}{c}\text { Sustainability Objectives } \\
\text { Objective } 1\end{array}$ & $\begin{array}{c}\text { Reformulated after the First Online Survey and the Interviews and } \\
\text { Submitted through the Second Online Survey }\end{array}$ \\
$\begin{array}{c}\text { Minimize environmental impacts } \\
\text { Maximize environmental services provided by the farm to the city } \\
80 \% \text { * }\end{array}$ & $\begin{array}{c}\text { Participate to urban metabolism and valorize the link to the city } \\
71 \% \text { * }\end{array}$ \\
\hline Objective 2 & $\begin{array}{c}\text { Have economic and ethical meaning } \\
82 \% \text { * }\end{array}$ \\
\hline Objective 3 & $\begin{array}{c}\text { Participate to food and environmental education } \\
82 \% \text { * }\end{array}$ \\
\hline Objective 4 & $\begin{array}{c}\text { Participate to consumer/producer connection } \\
76 \% \text { * }\end{array}$ \\
\hline Objective 5 & $\begin{array}{c}\text { Maximize socio-territorial services: } \\
\text { Objective } 6\end{array}$ \\
\hline$\%$ of the 45 respondents from the second online survey who declared the objectives as important.
\end{tabular}

During the second online survey, objective 6 was assessed as the least important by stakeholders, suggesting that they do not consider landscape services as a major goal for French PIUA. Objective 3 was assessed differently by (i) urban farmers and by (ii) decision makers and advisors: $91 \%$ of urban farmers declared that having economic and ethical meaning is important, and $74 \%$ of decision makers and advisors. This underlines that the only objective linked to the economic dimension of sustainable development is not one of the most important for decision makers. Despite this difference, all objectives were evaluated as important by the majority of respondents, and no complementary objective was suggested. We therefore considered that these six sustainability objectives express the goals French PIUA stakeholders are seeking to achieve when they implement PIUA projects.

\subsection{Sustainability Criteria}

The experts' focus group drafted 30 sustainability criteria applied to PIUA: 9 agro-environmental criteria, 13 socio-territorial criteria and 8 economic criteria. The experts suggested to split the criteria according to the three dimensions of sustainable development, and the authors suggested to name the dimensions according to the IDEA method [18]. The criteria were submitted to stakeholders' evaluation through online surveys and interviews and reformulated according to the same process as for the sustainability objectives. This evolution of the sustainability criteria is presented in Table 2 .

During the first online survey, six of the nine agro-environmental criteria were assessed as important or very important by the majority of respondents. Amongst them, criteria A5-Resources consumption, A6-Resources saving, A7-Environmental footprint, A8-Resource recycling and A9-Site planning and environment inclusion were assessed as important by around $80 \%$ of the respondents. Criteria A2-Wild biodiversity and A3-Process optimization were assessed as less important. Criteria A3-Process optimization was also mentioned as unclear by some respondents, as the difference between Resources-efficient process and Process optimization made by the group of experts was not understood by stakeholders. Amongst the 13 draft socio-territorial criteria, only five were considered as important by most of the respondents: B1-Partners on territory, B2-Anchoring to local network, B4-Link with inhabitants, B5. Knowledge sharing and training and B6-Jobs and working conditions. Regarding economic criteria only two criteria out of the eight draft criteria were considered as important by more than 
$60 \%$ of the respondents, namely C3-Involvement in local development and C1-Products value. Globally, eight respondents declared that criteria were incomplete or needed to be more specific.

Table 2. Evolution of sustainability criteria based on stakeholders' feedbacks. a. Agro-environmental criteria, b. Socio-territorial criteria, c. Economic criteria.

\begin{tabular}{|c|c|}
\hline \multicolumn{2}{|r|}{ (a) } \\
\hline $\begin{array}{l}\text { Drafted agro-Environmental Criteria } \\
\text { from the initial focus group }\end{array}$ & $\begin{array}{l}\text { Reformulated Agro-Environmental Criteria } \\
\text { after the first online survey and the interviews }\end{array}$ \\
\hline A1. Cropped biodiversity & A1. Cropped biodiversity: Number and types of species cultivated, breeds reared \\
\hline A2. Wild biodiversity & A2. Non cultivated biodiversity: Measures to enhance its conservation \\
\hline $\begin{array}{l}\text { A3. Process optimization } \\
\text { A4. Resources-efficient process }\end{array}$ & A3. Resources-efficient process: Measures to limit resources consumption \\
\hline $\begin{array}{l}\text { A5. Resources consumption } \\
\text { A6. Resources saving } \\
\text { A7. Environmental footprint }\end{array}$ & $\begin{array}{l}\text { A4. Resources consumption: Quantities of energy, water, or other inputs used, types of } \\
\text { inputs or energy used }\end{array}$ \\
\hline A8. Resource recycling & $\begin{array}{l}\text { A5. Resource recycling: Recycling of the resources used on the farm and use of } \\
\text { recycled inputs }\end{array}$ \\
\hline A9. Site planning and environment inclusion & $\begin{array}{l}\text { A6. Local pollution identification and technical adaptation: Risks of soil and/or air } \\
\text { pollution taken into account }\end{array}$ \\
\hline \multicolumn{2}{|r|}{ (b) } \\
\hline $\begin{array}{l}\text { Drafted Socio-Territorial Criteria } \\
\text { from the initial focus group }\end{array}$ & $\begin{array}{l}\text { Reformulated Socio-Territorial Criteria } \\
\text { after the first online survey and the interviews }\end{array}$ \\
\hline $\begin{array}{l}\text { B1. Partners on territory } \\
\text { B2. Anchoring to local network } \\
\text { B3. Suppliers' Policy }\end{array}$ & $\begin{array}{l}\text { B1. Partners on territory: Local network of suppliers, involvement in networks, } \\
\text { exchange of equipment, link with rural agriculture }\end{array}$ \\
\hline B4. Link with inhabitants & $\begin{array}{l}\text { B2. Link with inhabitants: Information, communication, involvement of local } \\
\text { inhabitants, open to public }\end{array}$ \\
\hline B5. Knowledge sharing and training & $\begin{array}{l}\text { B3. Knowledge sharing and education: Organization of conferences, training, } \\
\text { educational workshops }\end{array}$ \\
\hline B6. Jobs and working conditions & $\begin{array}{l}\text { B4. Working conditions and inclusion: Workload, design of the workspace, } \\
\text { employment of disabled workers or social insertion staff, gender equity }\end{array}$ \\
\hline B7. Risks management, hygiene and security & $\begin{array}{l}\text { B5. Risk management, health and security: Application of health standards and } \\
\text { regulations, management of sanitary issues on the workspace }\end{array}$ \\
\hline $\begin{array}{l}\text { B8. Contribution to governance } \\
\text { B9. Management and internal dialogue } \\
\text { B10. Governance transparency }\end{array}$ & $\begin{array}{l}\text { B6. Governance transparency and management: Internal and external communication } \\
\text { about governance, transparency of the decision making process, perception of internal } \\
\text { management }\end{array}$ \\
\hline $\begin{array}{l}\text { B11. Site planning and urban uses } \\
\text { B12. Urban planning } \\
\text { B13. Impact on landscape }\end{array}$ & $\begin{array}{l}\text { B7. Improvement of local living conditions: Valorization or maintenance of abandoned } \\
\text { spaces, restoration of old buildings, aesthetic quality and visibility of the landscape } \\
\text { design }\end{array}$ \\
\hline \multicolumn{2}{|r|}{ (c) } \\
\hline $\begin{array}{l}\text { Drafted Economic Criteria } \\
\text { from the initial focus group }\end{array}$ & $\begin{array}{l}\text { Reformulated Economic Criteria } \\
\text { after the first online survey and the interviews }\end{array}$ \\
\hline & $\begin{array}{l}\text { C1. Jobs: Number of jobs, types of contracts, local jobs } \\
\text { From B6-Jobs and working conditions (Draft socio-territorial criteria) }\end{array}$ \\
\hline C1. Products value & $\begin{array}{l}\text { C2. Financial value and economic return: Added value of the goods and services } \\
\text { produced, profitability }\end{array}$ \\
\hline C2. Sensory quality, health, services and labels & $\begin{array}{l}\text { C3. Sales channels, labels, and traceability: Short supply chain, products certified as } \\
\text { organic or with a territorial label, transformation of products }\end{array}$ \\
\hline C3. Involvement in local development & $\begin{array}{l}\text { Included in B1-Partners on territory } \\
\text { (Reformulated socio-territorial criteria) }\end{array}$ \\
\hline C4. Distribution of revenues & C4. Sources of revenue: Share of revenue per client and per activity \\
\hline $\begin{array}{l}\text { C5. Redistribution to collaborators } \\
\text { C6. Redistribution to stakeholders }\end{array}$ & $\begin{array}{l}\text { C5. Redistribution to collaborators and stakeholders: Affordable prices, prices adapted } \\
\text { to the type of clients, salary scale, products donation }\end{array}$ \\
\hline C7. Financial contributions and subsidies & $\begin{array}{l}\text { C6. Weights of grants and subsidies: Amount of subsidies received compared to the } \\
\text { result }\end{array}$ \\
\hline \multirow[t]{2}{*}{ C8. Farm transferability } & $\begin{array}{l}\text { C7. Project continuity: Type of lease agreement, possibility to move the farm to another } \\
\text { site, financial debt }\end{array}$ \\
\hline & $\begin{array}{l}\text { C8. Project leader's status: Background, training, working experiences in agriculture } \\
\text { New criteria }\end{array}$ \\
\hline
\end{tabular}


The results of the first online survey underlined the need to review the sustainability criteria to better represent the stakeholders' view of sustainable PIUA, and more specifically to reformulate some of them thanks to interviews. The interviews carried out with decision makers, urban farmers and advisors led to a set of six agro-environmental criteria, seven socio-territorial criteria and eight economic criteria. Most of the changes were rewording and merging of existing criteria. Moreover, a new criterion was added to the economic dimension, linked to urban farmers' status: C8-Project leader's status: Background, training, working experiences in agriculture. This new criteria was mentioned by local authorities and advisors during several interviews, arguing that as numerous urban farmers had a career change, having a background in agriculture should be a criteria to assess their ability to manage a farm, and therefore ensure the sustainability of the farm.

After the interviews, the reformulated criteria were submitted to stakeholders through a second online survey alongside with short descriptions, as detailed in Table 2. Within the second survey, all six agro-environmental criteria were assessed as important or very important by a majority of respondents, as presented in Figure 2.

The reformulation process was successful, as the perception of respondents improved between the two surveys. However, some criteria were assessed as being more important than others. Criteria A3-Resources-efficient process, A4-Resources consumption and A5-Resources recycling were mainly assessed as important or very important, showing that stakeholders are mostly concerned by resources related issues that can be beneficial, when the farm recycles organic waste for instance, or detrimental, when it consumes high quantities of energy or water. Criteria A6-Local pollution identification and technical adaptation is also assessed as very important, underlining that stakeholders seriously take into account the risk of soil and air pollution. Amongst respondents, $91 \%$ of decision makers and advisors assessed criteria A6 as important, compared with $64 \%$ of the urban farmers, showing that this concern is mostly on the side of decision makers, such as local authorities. Criteria A1—Cropped biodiversity and A2-Non cultivated biodiversity are assessed as less important than the others, whereas it is an aspect often discussed in the literature $[25,26]$. Those two criteria were assessed differently by urban farmers and decision makers or advisors: urban farmers considered cropped biodiversity as more important than non-cultivated biodiversity, whereas it was the opposite for decision makers and advisors.

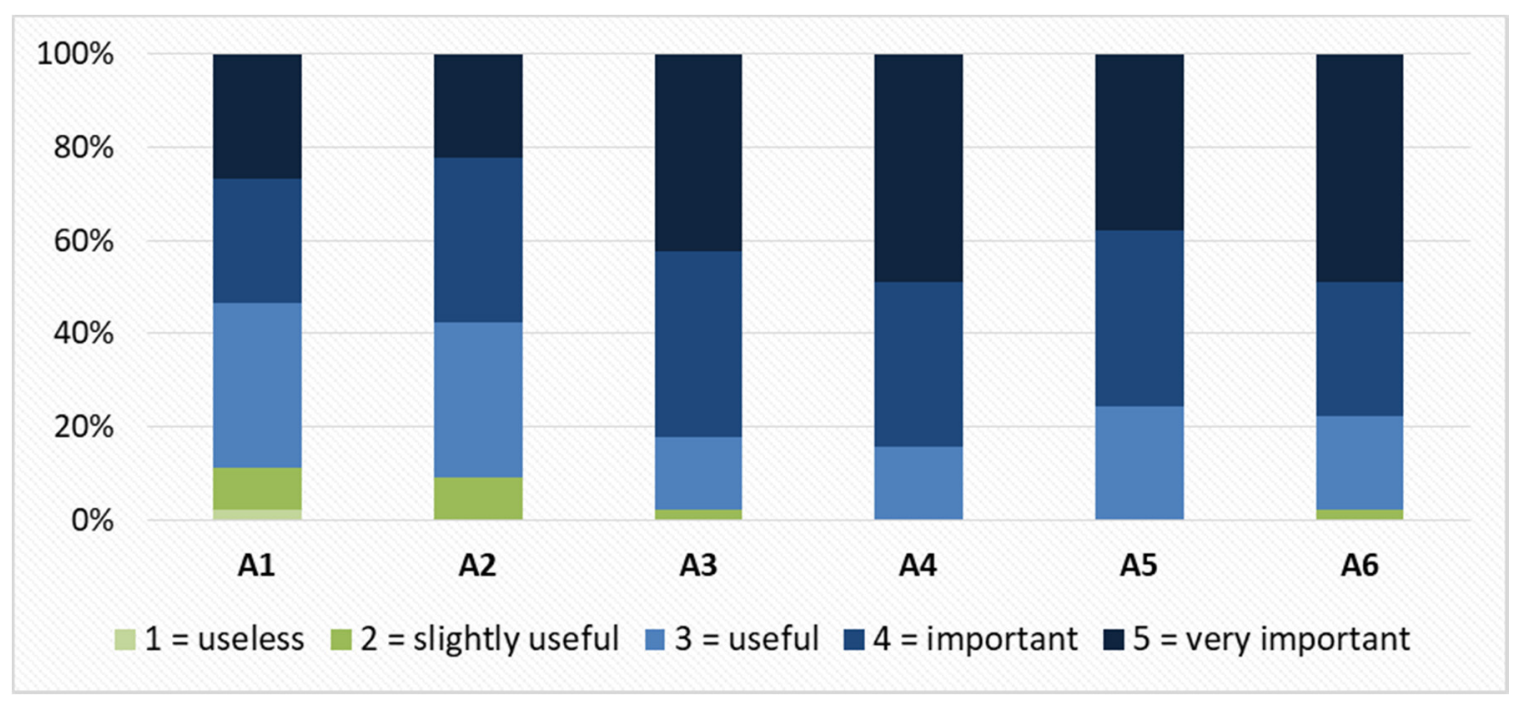

(a) A1-Cropped biodiversity, A2-Non cultivated biodiversity, A3-Resources efficient process, A4-Resources consumption, A5-Resources recycling, A6-Local pollution identification and technical adaptation.

Figure 2. Cont. 


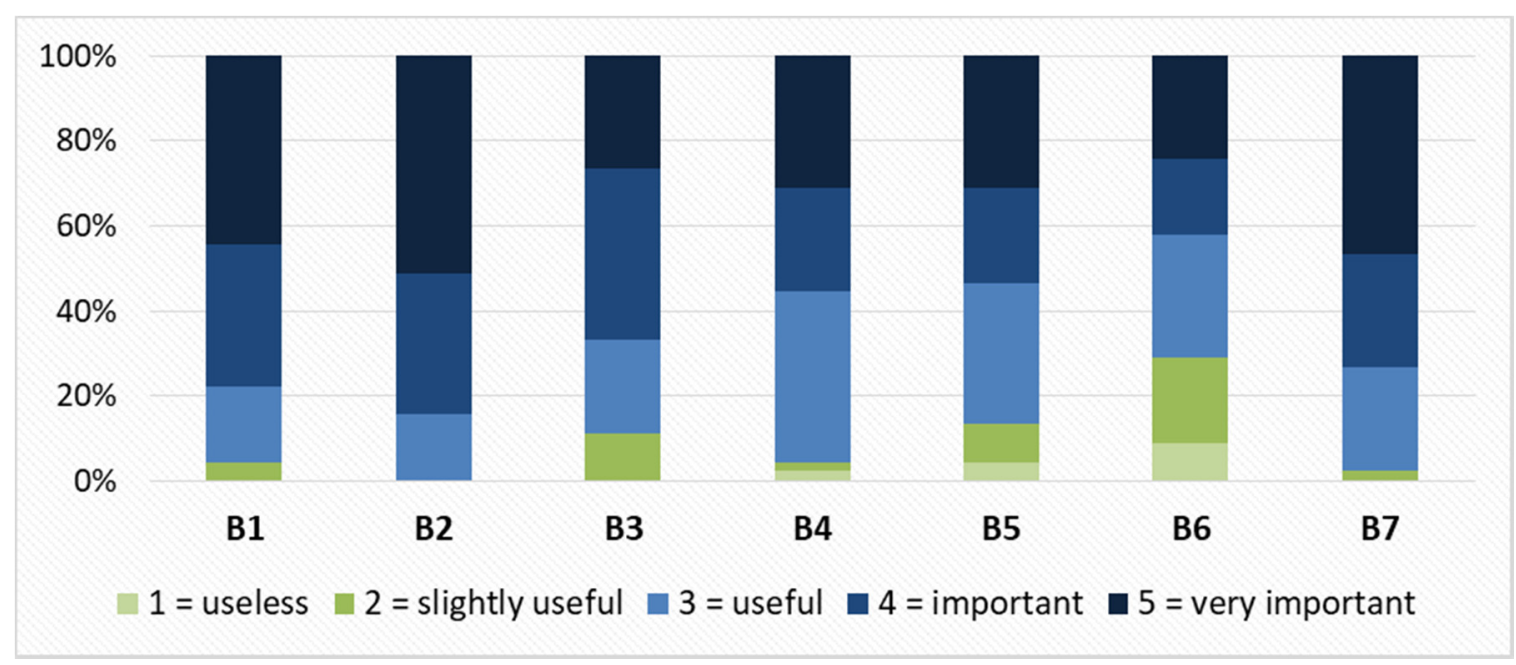

(b) B1-Partners on territory, B2-Link with inhabitants, B3-Knowledge sharing and education, B4-Working conditions and inclusion, B5-Risk management, health and security, B6Governance transparency and management, B7-Improvement of local living conditions.

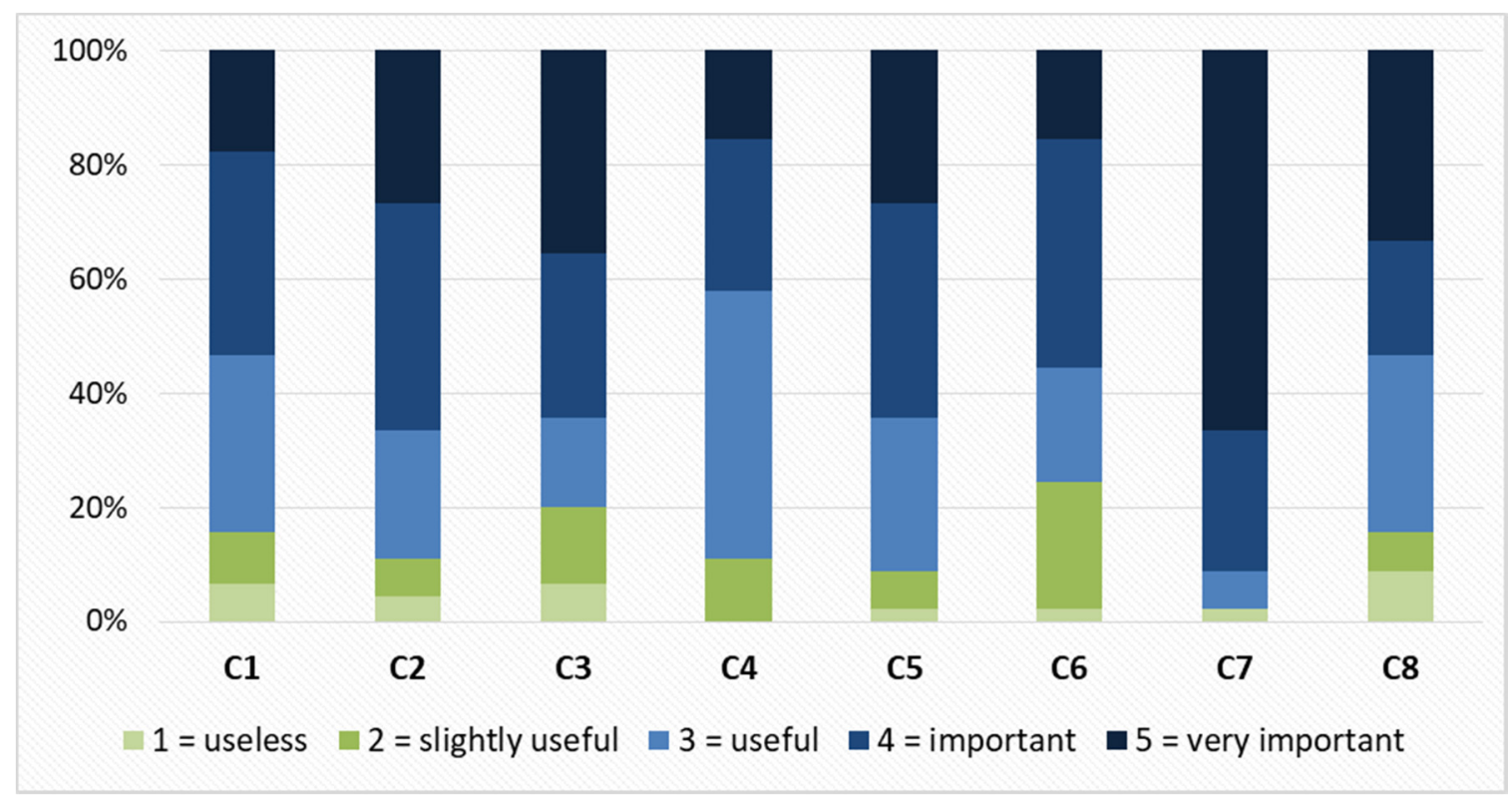

(c) C1-Jobs, C2-Financial value and economic return, C3-Sales channel, labels, traceability, C4-Sources of revenue, C5-Redistribution to collaborators and stakeholders, C6-Weight of grants and subsidies, C7-Project continuity, C8-Project leader's status.

Figure 2. Perception of reformulated sustainability criteria by the 45 respondents of online survey 2 from level 1 (pale green) = useless to level 5 (dark blue) = very important. (a) Agro-environmental criteria; (b) Socio-territorial criteria; (c) Economic criteria.

Regarding socio-territorial dimension, six criteria out of seven were assessed as important or very important by a majority of respondents. Criteria B1-Partners on territory, B2 - Link with inhabitants and B7-Improvement of local living conditions were evaluated as the most important of the socio-territorial criteria, highlighting the crucial role of interactions the farm should develop with the surrounding city. Criterion B3-Knowledge sharing and education was evaluated as less important, but mainly by urban farmers, as 70\% of decision makers and advisors assessed it as level four or five. 
Criteria B4-Working conditions and inclusion, B5-Risk management, health and security, and especially B6-Governance transparency and management, were assessed with lower levels of importance. Criteria B6 includes communication about governance, decision making process, and ways the internal management of the PIUA farm is perceived by the farm workforce. Only $30 \%$ of the decision makers and advisors assessed it as important or very important, compared with 55\% of urban farmers. This suggests that aspects linked to internal management and governance are of primary interest for urban farmers, and not considered as crucial by other stakeholders. Within the socio-territorial dimension, criteria dealing with impacts on a large scale, especially benefits for the city, are of primary importance for decision makers and advisors, whereas urban farmers also consider as important the criteria linked to internal aspects of the farm.

Within the economic pillar, the results were more mixed, with hardly more than $50 \%$ of the votes corresponding to levels four or five. This suggests that the economic criteria are perceived by stakeholders as less important than agro-environmental or socio-territorial ones. The only economic criterion which was largely assessed as important or very important was criterion C7—Project continuity, dealing with the type of lease agreement, the possibility to move the farm to another site of the financial debt. It is also interesting to note that between the first and second survey, the reformulation of criteria led to moving one economic criterion to the socio-territorial dimension, and one socio-territorial criterion to the economic dimension. This underlines the porosity of the boundary between socio-territorial and economic dimensions.

A new criterion was also added during the reformulation process, C8-Project leader's status, which deals with urban farmer's background, training, and working experience in agriculture. This criteria was assessed as level four or five by $70 \%$ of decision makers and advisors, and only $36 \%$ of urban farmers, showing that decision makers and advisors give significant weight to the agronomic skills of urban farmers to ensure that they will be able to run the farm they want to support.

Amongst the economic criteria, the ones assessed as less important as the others are criteria C4-Sources of revenue, C1-Jobs and especially C6-Weight of grants and subsidies. This suggests that the subsidization of PIUA projects is not perceived as a major threat to their sustainability. Criterion C3-Sales channels labels and traceability is assessed as important or very important by $70 \%$ of decision makers and advisors, but by only $59 \%$ of urban farmers, showing that short supply chains and territorial approach are of primary interest for decision makers.

Eventually, the final set of criteria includes six agro-environmental criteria, seven socio-territorial criteria, and eight economic criteria, which correspond to the reformulated criteria presented in Table 2.

\section{Discussion}

\subsection{An Original Set of Objectives Compared to the Ones Defined for Rural Farms}

Sustainability objectives of existing tools and frameworks have been defined to assess rural farms sustainability [18], but not to assess urban agriculture [7-9]. However, most of our objectives are partially or fully original, compared to the ones defined to assess rural farms. Objective two-Participate to urban metabolism and valorize the link to the city is fully original and cannot be found in existing tools to assess rural farms. Objective five-Participate to consumer/producer connection can also be considered as original as the link between agricultural producers and consumers is not clearly put forward in existing tools.

Objective one-Maximize environmental services provided by the farm to the city is partly original. Other tools consider environmental objectives, such as preserving natural resources [18] or maximizing green services and blue services [16], but do not specifically focus on the city context. Objective six-Maximize socio-territorial services: re-appropriation of space and landscape services is also partly original as landscapes services are mentioned in other tools [18]; but re-appropriation of space is not mentioned, whereas it has been published that urban agriculture projects implemented on vacant land provide social benefits such as re-appropriation [27]. 
Five out of six objectives are fully related to benefits for the whole society and correspond to external (or global) sustainability. External sustainability is described as the societal issues faced by farmers and farming in general [18], but also as the vision urban planners and residents have about urban agriculture [28]. Therefore, PIUA seems to be perceived by French stakeholders as an answer to societal challenges, even before food production, as no objective of food production has been directly mentioned.

Only objective three deals with internal sustainability, the sustainability of the farm itself, when it refers to economic meaning. Objectives such as contributing to quality of life or maintaining independence and freedom to act, which are included in the IDEA tool are not mentioned by stakeholders. This indicates that internal sustainability is not part of the main objectives of the French PIUA sector, as they mainly aim at maximising the positive impacts of the farm on its urban environment, and minimising the negative ones.

Objectives have been set up in order to agree on a shared vision of what is defined as sustainable PIUA, as has been done for the IDEA method in the rural agriculture context [18]. Then, criteria have been defined, however they have not been clearly linked to the objectives, even if they belong to the conceptual framework based on the objectives-in order to avoid a too normative approach where compensation between criteria linked to the same objective is allowed.

\subsection{Criterias' Hierarchy Reflecting Stakeholders' Expectations from PIUA}

Regarding sustainable criteria identified in our study, it appears that agro-environmental and socio-territorial criteria are assessed as more important than economic criteria, as already shown in a study taking place in Italy [29]. This might suggest that environmental and social services delivered by the farm to the city can be paid in order to reach internal economic sustainability. As decision makers assess the criteria C6-Weight of grants and subsidies as less important, it suggests that they might be ready to subsidize the farms, and so to participate in the remuneration of the multiple environmental and social services provided by the farm.

As for the sustainability objectives, criteria assessed as the most important are the ones related to the impacts of the farm on society and environment, illustrating the strong expectations in regards to PIUA. Here again, food production is not mentioned as a sustainability criteria, pushing food production into the background. This could be explained by two hypotheses: for some stakeholders, food production is only the support of environmental or social services which are the major goals of the farm. For other stakeholders, production is a major economic goal, to develop a business that is economically viable, but the fact that it is food production instead of another production is not the major goal. In both cases food production is secondary, and this can explain why it was not mentioned by stakeholders.

We also observe a difference between decision makers and urban farmers: for urban farmers, internal management or diversity of crops are important, which are criteria found in the literature specific to rural farms $[18,21,30]$. On the other hand, decision makers and advisors give more importance to pollution management, impact on non-cultivated biodiversity, educational aspects, training of the farmer, or type of lease agreement. These stakeholders are therefore well aware of the risks linked to the lack of agricultural background, polluted soils or insecure land use which have already been identified in the literature $[29,31,32]$. It is interesting to note that all criteria are linked to one or several sustainability objectives, except for criteria C8-Project leader's status: Background, training, working experiences in agriculture, which does not correspond to any objective. This highlights the specific role of this criteria, especially for decision makers and advisors who assessed it as very important. The role given to the agricultural background of the urban farmers might be a way to transfer responsibility for internal sustainability of the farm from the decision makers to the urban farmers, explaining why decision makers and advisors focus mainly on external sustainability of PIUA projects.

Urban farmers and decision makers might have different perception of PIUA sustainability criteria, but these two visions are complementary. By combining the urban farmers' approach where internal 
sustainability is very important, and the decision makers' approach where external sustainability is most important, the global sustainability concept of PIUA might be reached.

\subsection{Different Trends for Urban Agriculture in Global North and Global South Countries}

The results of our case study carried out in France meet the ones published in Italy, where sustainability of urban agriculture is also described as multi-scalar, with predominant sustainability benefits at the city scale [29]. Another case study from Italy, Spain, Germany, and France outlines the presence of specific sustainability aspects and overall sustainability aspects of urban agriculture projects [33], meeting our result regarding the external and internal sustainability of PIUA in France. It also pointed out that in most cases, external stakeholders played an important role in supporting the projects, which supports our finding about the willingness of decision makers to fund PIUA initiatives. Even out of Europe, a study of five rooftop farms in Hong Kong highlighted that the benefits can be considered as being social rather than relative to food security, which converge with our result putting food production into the background [14].

In global South countries, the situation is different as urban agriculture play a major role in food security for urban populations: in Kinshasa, Democratic Republic of Congo, 65\% of the city's supply in vegetables is produced within urban gardens [34]; $95 \%$ of the watercress consumed in Antananarivo, Madagascar is produced within the city [35], and 65 to $70 \%$ of vegetables are produced and consumed by inhabitants in Dakar, Senegal [36]. Social benefits are also identified for urban agriculture in global South countries, but deal more often with direct benefits for the farmers, such as increased source of revenues [37] or social cohesion between producers [38] rather than global benefits for the society.

\subsection{Transferability of Our Results in Other Contexts}

Our study focuses on French PIUA, excluding peri-urban farms and community gardens as defined by the Institute for Urban Planning and Development of the Île-de-France Region [3]. The sustainability criteria developed in this study might be applied out of France, on urban farms in global North countries, as objectives seem quite similar as discussed in the section above. However, the application on peri-urban farms in the global North countries, or on urban farms in the global South countries, might not be relevant as for those farms food production is a major goal.

Regarding community gardens, a case study in Germany [39] presents goals of urban gardening projects which are similar to the ones that we identified: the goal Environment and ecology is close to our Objective 1-Minimize environmental impacts and maximize environmental services provided by the farm to the city; the goal Education is close to our Objective four-Participate to food and environmental education. However other goals such as Social community or Intercultural communities or Therapeutic approach were identified as important for urban gardens and were not mentioned during our participatory process. Indeed, positive impacts of urban gardening on health issues such as reducing stress levels, or on social issues such as social cohesion, have been described in the literature [40,41]. As it is not included in the objectives we developed, a direct application of our sustainability criteria on community gardens might not be relevant.

\section{Conclusions}

Our study identified a set of sustainable objectives and criteria applicable to French PIUA. The objectives are mainly related to external sustainability, highlighting that stakeholders expects PIUA to have many impacts on the sustainable development of cities. The participatory process of our study allows us to identify the importance given to the different objectives and criteria by the stakeholders. Agro-environmental and socio-territorial criteria are assessed as more important than economic criteria. PIUA sustainability fits into the trends observed in Europe, or Hong Kong, with an emphasis on external sustainability aspects, aiming environmental, social and economic benefits for the global society, and pushing aside food production. The opposite can be found in global South countries where food production is a major goal for urban agriculture, completed by benefits directly 
aimed at the farmers. The sustainability criteria developed in this study might be applied on urban farms in other global North countries, however their direct application on urban farms in the global South or on peri-urban farms and community gardens in the global North might not be relevant.

Therefore, it seems that sustainable PIUA in France is a form of agriculture that provides a variety of services to the city and city dwellers apart from food production, and that decision makers are ready to subsidize these projects. Decision makers and advisors focus on urban farmers' background, suggesting that they also rely on urban farmers to ensure internal sustainability of the farm.

By relying on our results, indicators could be designed to measure the sustainability criteria identified, and to allow the sustainability assessment of PIUA projects, as expected by PIUA stakeholders.

Author Contributions: Both authors P.C. and A.F.-L. took part in the development of the research project, gathering and analysis of data, and drafting of the manuscript. All authors have read and agreed to the published version of the manuscript.

Funding: This work was supported by the Urban Agriculture Chair of AgroParisTech, and has received funding from the European Union's Horizon 2020 research and innovation program under grant agreement No. 862663. The publication reflects the author's views. The Research Executive Agency (REA) is not liable for any use that may be made of the information contained therein.

Acknowledgments: We are grateful to all the stakeholders of the French PIUA sector involved in the workshop, online surveys and interviews for their participation. We also thank Jean-Marc Meynard (INRAE) for his kind support and proofreading.

Conflicts of Interest: The authors declare no conflict of interest. A.F.-L. is a member of the Scientific Committee of the Urban Agriculture Chair of AgroParisTech and of the scientific council of the Dotation Fund for the development of urban agriculture of the city of Romainville.

\section{Appendix A}

Table A1. Reformulated sustainability objectives of PIUA in English and French.

\begin{tabular}{|c|c|c|}
\hline $\begin{array}{c}\text { Reformulated } \\
\text { Sustainability Objectives }\end{array}$ & English Version (Translated) & French Version (Original) \\
\hline Objective 1 & $\begin{array}{l}\text { Minimize environmental impacts } \\
\text { Maximize environmental services } \\
\text { provided by the farm to the city }\end{array}$ & $\begin{array}{l}\text { Minimiser les impacts } \\
\text { environnementaux } \\
\text { Maximiser les services } \\
\text { environnementaux rendus par } \\
\text { la ferme à la ville }\end{array}$ \\
\hline Objective 2 & $\begin{array}{l}\text { Participate to urban metabolism } \\
\text { and valorize the link to the city }\end{array}$ & $\begin{array}{l}\text { Participer au métabolisme urbain et } \\
\text { valoriser par le lien à la ville }\end{array}$ \\
\hline Objective 3 & $\begin{array}{l}\text { Have economic and ethical } \\
\text { meaning }\end{array}$ & Avoir du sens économique et éthique \\
\hline Objective 4 & $\begin{array}{l}\text { Participate to food and } \\
\text { environmental education }\end{array}$ & $\begin{array}{l}\text { Participer à l'éducation à } \\
\text { l'environnement et à l'alimentation }\end{array}$ \\
\hline Objective 5 & $\begin{array}{l}\text { Participate to consumer/producer } \\
\text { connection }\end{array}$ & $\begin{array}{l}\text { Participer au rapprochement entre } \\
\text { consommateur et producteur }\end{array}$ \\
\hline Objective 6 & $\begin{array}{l}\text { Maximize socio-territorial services: } \\
\text { Re-appropriation of space and } \\
\text { landscape services }\end{array}$ & $\begin{array}{l}\text { Maximiser les services socio-territoriaux } \\
\text { rendus à la ville: (ré) appropriation de } \\
\text { l'espace et services paysagers }\end{array}$ \\
\hline
\end{tabular}


Table A2. Reformulated sustainability criteria of PIUA in English and French. a. Agro-environmental criteria, b. Socio-territorial criteria, c. Economic criteria.

\begin{tabular}{|c|c|}
\hline \multicolumn{2}{|c|}{ (a) } \\
\hline $\begin{array}{c}\text { Reformulated Agro-Environmental Criteria } \\
\text { English version (translated) }\end{array}$ & $\begin{array}{l}\text { Reformulated Agro-Environmental Criteria } \\
\text { French version (original) }\end{array}$ \\
\hline $\begin{array}{l}\text { A1. Cropped biodiversity: Number and types of } \\
\text { species cultivated, breeds reared }\end{array}$ & $\begin{array}{l}\text { A1. Biodiversité cultivée: Nombre et types d'espèces } \\
\text { cultivées et de races élevées }\end{array}$ \\
\hline $\begin{array}{l}\text { A2. Non cultivated biodiversity: Measures to } \\
\text { enhance its conservation }\end{array}$ & $\begin{array}{l}\text { A2. Biodiversité non-cultivée: Mesures qui favorisent } \\
\text { sa préservation }\end{array}$ \\
\hline $\begin{array}{l}\text { A3. Resources-efficient process: Measures to limit } \\
\text { resources consumption }\end{array}$ & $\begin{array}{l}\text { A3. Sobriété du process: Mesures qui permettent de } \\
\text { limiter la consommation de ressources }\end{array}$ \\
\hline $\begin{array}{c}\text { A4. Resources consumption: Quantities of energy, } \\
\text { water, or other inputs used, types of inputs or energy } \\
\text { used }\end{array}$ & $\begin{array}{l}\text { A4. Consommation de ressources: Quantité } \\
\text { d'énergie, d'eau, semences, intrants consommés, } \\
\text { types d'intrants et énergie utilisés }\end{array}$ \\
\hline $\begin{array}{l}\text { A5. Resource recycling: Recycling of the resources } \\
\text { used on the farm and use of recycled inputs }\end{array}$ & $\begin{array}{l}\text { A5. Recyclage des ressources: Recyclage des } \\
\text { ressources utilisées, des co-produits et utilisation de } \\
\text { matériaux recyclés }\end{array}$ \\
\hline $\begin{array}{l}\text { A6. Local pollution identification and technical } \\
\text { adaptation: Risks of soil and/or air pollution taken } \\
\text { into account }\end{array}$ & $\begin{array}{l}\text { A6. Prise en compte des pollutions locales et } \\
\text { adaptation des pratiques: Considération des risques } \\
\text { de pollution du sol et atmosphérique sur le site }\end{array}$ \\
\hline \multicolumn{2}{|c|}{ (b) } \\
\hline $\begin{array}{l}\text { Reformulated Socio-Territorial Criteria } \\
\text { English version (translated) }\end{array}$ & $\begin{array}{l}\text { Reformulated Socio-Territorial Criteria } \\
\text { French version (original) }\end{array}$ \\
\hline $\begin{array}{l}\text { B1. Partners on territory: Local network of suppliers, } \\
\text { involvement in networks, exchange of equipment, } \\
\text { link with rural agriculture }\end{array}$ & $\begin{array}{l}\text { B1. Partenaires sur le territoire: Réseau local de } \\
\text { fournisseurs et clients, inclusion dans des réseaux, } \\
\text { échange de matériel, lien avec le milieu rural }\end{array}$ \\
\hline $\begin{array}{l}\text { B2. Link with inhabitants: Information, } \\
\text { communication, involvement of local inhabitants, } \\
\text { open to public }\end{array}$ & $\begin{array}{l}\text { B2. Lien avec les habitants: Information, } \\
\text { communication, concertation, participation des } \\
\text { habitants, accueil du public }\end{array}$ \\
\hline $\begin{array}{l}\text { B3. Knowledge sharing and education: Organization } \\
\text { of conferences, training, educational workshops }\end{array}$ & $\begin{array}{l}\text { B3. Partage des connaissances et formation: } \\
\text { Organisation de conférences, formations, ateliers } \\
\text { pédagogiques }\end{array}$ \\
\hline $\begin{array}{l}\text { B4. Working conditions and inclusion: Workload, } \\
\text { design of the workspace, employment of disabled } \\
\text { workers or social insertion staff, gender equity }\end{array}$ & $\begin{array}{l}\text { B4. Conditions de travail et inclusion: Charge de } \\
\text { travail, lieu de travail, pénibilité des tâches, } \\
\text { travailleurs avec handicap ou en insertion, égalité } \\
\text { homme-femme }\end{array}$ \\
\hline $\begin{array}{l}\text { B5. Risk management, health and security: } \\
\text { Application of health standards and regulations, } \\
\text { management of sanitary issues on the workspace }\end{array}$ & $\begin{array}{l}\text { B5. Management des risques, hygiène et sécurité: } \\
\text { Gestion de la pollution, risques divers sur le lieu de } \\
\text { travail, respect des normes et règlementations } \\
\text { sanitaires }\end{array}$ \\
\hline $\begin{array}{l}\text { B6. Governance transparency and management: } \\
\text { Internal and external communication about } \\
\text { governance, transparency of the decision making } \\
\text { process, perception of internal management }\end{array}$ & $\begin{array}{l}\text { B6. Transparence organisationnelle et management: } \\
\text { Communication interne et externe autour de la } \\
\text { gouvernance, process de prise de décision } \\
\text { transparent, perception du management interne }\end{array}$ \\
\hline $\begin{array}{l}\text { B7. Improvement of local living conditions: } \\
\text { Valorization or maintenance of abandoned spaces, } \\
\text { restoration of old buildings, aesthetic quality and } \\
\text { visibility of the landscape design }\end{array}$ & $\begin{array}{l}\text { B7. Amélioration du cadre de vie local, des } \\
\text { conditions de vie: Valorisation et entretien d'espaces, } \\
\text { réhabilitation de bâtiments, accessibilité et qualité } \\
\text { paysagère des aménagements, création de lien social }\end{array}$ \\
\hline
\end{tabular}


Table A2. Cont.

\section{(c)}

\section{Reformulated Economic Criteria English version (translated)}

\section{Reformulated Economic Criteria French version (original)}

\begin{tabular}{|c|c|}
\hline C1. Jobs: Number of jobs, types of contracts, local jobs & $\begin{array}{c}\text { C1. Emplois: Nombre de postes, types de postes, } \\
\text { emplois locaux }\end{array}$ \\
\hline $\begin{array}{l}\text { C2. Financial value and economic return: Added } \\
\text { value of the goods and services produced, } \\
\text { profitability }\end{array}$ & $\begin{array}{l}\text { C2. Valeur financière et rentabilité économique: } \\
\text { Valeur ajoutée des biens et services produits, } \\
\text { rentabilité économique et profitabilité }\end{array}$ \\
\hline $\begin{array}{l}\text { C3. Sales channels, labels, and traceability: Short } \\
\text { supply chain, products certified as organic or with a } \\
\text { territorial label, transformation of products }\end{array}$ & $\begin{array}{l}\text { C3. Circuits de vente, labels et traçabilité: Circuit } \\
\text { court, agriculture biologique, label territorial, } \\
\text { transformation }\end{array}$ \\
\hline $\begin{array}{l}\text { C4. Sources of revenue: Share of revenue per client } \\
\text { and per activity }\end{array}$ & $\begin{array}{l}\text { C4. Origine du chiffre d'affaire: Répartition des } \\
\text { différentes sources de revenus par type d'activité et } \\
\text { par client }\end{array}$ \\
\hline $\begin{array}{l}\text { C5. Redistribution to collaborators and stakeholders: } \\
\text { Affordable prices, prices adapted to the type of } \\
\text { clients, salary scale, products donation }\end{array}$ & $\begin{array}{l}\text { C5. Redistribution aux collaborateurs et aux parties } \\
\text { prenantes: Offre de produits de qualité à un prix } \\
\text { accessible, adaptation des prix au type de clientèle, } \\
\text { répartition des salaires, donc de tout ou parties de la } \\
\text { production }\end{array}$ \\
\hline $\begin{array}{l}\text { C6. Weights of grants and subsidies: Amount of } \\
\text { subsidies received compared to the result }\end{array}$ & $\begin{array}{c}\text { C6. Importance des aides et subventions: Montant } \\
\text { des aides et subventions perçues par rapport au } \\
\text { résultat }\end{array}$ \\
\hline $\begin{array}{l}\text { C7. Project continuity: Type of lease agreement, } \\
\text { possibility to move the farm to another site, } \\
\text { financial debt }\end{array}$ & $\begin{array}{l}\text { C7. Pérennité du projet: Situation foncière, } \\
\text { endettement, déplacement possible des } \\
\text { aménagements }\end{array}$ \\
\hline $\begin{array}{l}\text { C8. Project leader's status: Background, training, } \\
\text { working experiences in agriculture }\end{array}$ & $\begin{array}{l}\text { C8. Profil du porteur de projet: Formation, } \\
\text { expériences professionnelles agricoles }\end{array}$ \\
\hline
\end{tabular}

\section{References}

1. Azunre, G.A.; Amponsah, O.; Peprah, C.; Takyi, S.A.; Braimah, I. A review of the role of urban agriculture in the sustainable city discourse. Cities 2019, 93, 104-119. [CrossRef]

2. Daniel, A.-C. Aperçu de L'agriculture Urbaine en Europe et en Amérique du Nord; AgroParisTech: Paris, France, 2013; p. 79.

3. Institut d'aménagement et d'urbanisme. Île-de-France Note Rapide n779—L'agriculture Urbaine au Coeur des Projets de Ville: Une Diversité de Formes et de Fonctions; Institut d'aménagement et d'urbanisme: Paris, France, 2018.

4. Opitz, I.; Berges, R.; Piorr, A.; Krikser, T. Contributing to food security in urban areas: Differences between urban agriculture and peri-urban agriculture in the Global North. Agric. Hum. Values 2015, 33, 341-358. [CrossRef]

5. France Urbaine Villes. Agriculture et Alimentation: Expériences Françaises; France Urbaine Villes: Paris, France, 2018 ; p. 68.

6. Mayol, P.; Gangneron, E. L'agriculture Urbaine: Un Outil Déterminant Pour des villes Durables. Les avis du CESE. 2019, 15, 98.

7. Altman, L.; Barry, L.; Barry, M.; Kühl, K.; Silva, P.; Wilks, B.; Bauer, C.; Fletcher, R. Five Borough Farm II: Growing the Benefits of Urban Agriculture in New York City; Design Trust for Public Space (Organization): New York, NY, USA, 2014; ISBN 978-0-9777175-9-0.

8. Teitel-Payne, R.; Kuhns, J.; Nasr, J. Indicators for Urban Agriculture in Toronto: A Scoping Analysis. Available online: http://www.fao.org/urban-food-actions/knowledge-products/resources-detail/fr/c/1043653/ (accessed on 10 September 2020).

9. MacKenzie, S.G.; Davies, A.R. SHARE IT: Co-designing a sustainability impact assessment framework for urban food sharing initiatives. Environ. Impact Assess. Rev. 2019, 79, 106300. [CrossRef] [PubMed] 
10. Grard, B.J.-P.; Chenu, C.; Manouchehri, N.; Houot, S.; Frascaria-Lacoste, N.; Aubry, C. Rooftop farming on urban waste provides many ecosystem services. Agron. Sustain. Dev. 2017, 38, 2. [CrossRef]

11. Lin, B.; Philpott, S.M.; Jha, S. The future of urban agriculture and biodiversity-ecosystem services: Challenges and next steps. Basic Appl. Ecol. 2015, 16, 189-201. [CrossRef]

12. Langemeyer, J.; Baró, F.; Roebeling, P.C.; Gómez-Baggethun, E. Contrasting values of cultural ecosystem services in urban areas: The case of park Montjuic in Barcelona. Ecosyst. Serv. 2015, 12, 178-186. [CrossRef]

13. Petit-Boix, A.; Apul, D. From Cascade to Bottom-Up Ecosystem Services Model: How Does Social Cohesion Emerge from Urban Agriculture? Sustainability 2018, 10, 998. [CrossRef]

14. Wang, T.; Pryor, M. Social Value of Urban Rooftop Farming: A Hong Kong Case Study. Agricul. Econ. Curr. Issues 2019. [CrossRef]

15. Kim, E.; Jung, J.; Hapsari, T.G.; Kang, S.; Kim, K.; Yoon, S.; Lee, M.; Han, M.Y.; Choi, Y.; Choe, J.K. Economic and environmental sustainability and public perceptions of rooftop farm versus extensive garden. Build. Environ. 2018, 146, 206-215. [CrossRef]

16. Meul, M.; Van Passel, S.; Nevens, F.; Dessein, J.; Rogge, E.; Mulier, A.; Van Hauwermeiren, A. MOTIFS: A monitoring tool for integrated farm sustainability. Agron. Sustain. Dev. 2008, 28, 321-332. [CrossRef]

17. Bockstaller, C.; Guichard, L.; Keichinger, O.; Girardin, P.; Galan, M.-B.; Gaillard, G. Comparison of methods to assess the sustainability of agricultural systems. A review. Agron. Sustain. Dev. 2009, 29, 223-235. [CrossRef]

18. Zahm, F.; Ugaglia, A.A.; Barbier, J.-M.; Boureau, H. Evaluating sustainability of farms: Introducing a new conceptual framework based on three dimensions and five key properties relating to the sustainability of agriculture. The IDEA method version 4. In Proceedings of the 13th European Farming Systems Symposium Farming Systems: Facing Uncertainties and Enhancing Opportunities, Chania, Greece, 1-5 July 2018.

19. López-Ridaura, S. Evaluating the sustainability of complex socio-environmental systems. the MESMIS framework. Ecol. Indic. 2002, 2, 135-148. [CrossRef]

20. Lelièvre, A.; Clerino, P. Developing a tool to evaluate the sustainability of intra-urban farms. In Proceedings of the 13th European IFSA Symposium. Farming Systems: Facing Uncertainties and Enhancing Opportunities, Chania, Greece, 1-5 July 2018.

21. FAO. SAFA (Sustainability Assessment of Food and Agriculture systems) Tool: User Manual Version 2.2.40; Food and Agriculture Organization of the United Nations (FAO): Roma, Italy, 2013; p. 30.

22. Craheix, D.; Angevin, F.; Bergez, J.-E.; Bockstaller, C.; Colomb, B.B.; Guichard, L.L.; Reau, R.; Doré, T. MASC 2.0, un outil d'évaluation multicritère pour estimer la contribution des systèmes de culture au développement durable. Innov. Agron. 2012, 20, 35-48.

23. Bockstaller, C.; Girardin, P.; Van Der Werf, H. Use of agro-ecological indicators for the evaluation of farming systems. Eur. J. Agron. 1997, 7, 261-270. [CrossRef]

24. Les adhérents. AFAUP-Association Française d'Agriculture Urbaine Professionelle. Available online: http: //www.afaup.org/les-adherents/ (accessed on 10 September 2020).

25. Camps-Calvet, M.; Langemeyer, J.; Calvet-Mir, L.; Gomez-Baggethun, E. Ecosystem services provided by urban gardens in Barcelona, Spain: Insights for policy and planning. Environ. Sci. Policy 2016, 62, 14-23. [CrossRef]

26. Madre, F.; Vergnes, A.; Machon, N.; Clergeau, P. Green roofs as habitats for wild plant species in urban landscapes: First insights from a large-scale sampling. Landsc. Urban Plan. 2014, 122, 100-107. [CrossRef]

27. Németh, J.; Langhorst, J. Rethinking urban transformation: Temporary uses for vacant land. Cities 2014, 40, 143-150. [CrossRef]

28. Ba, A.; Aubry, C. Diversité et durabilité de l'agriculture urbaine: Une nécessaire adaptation des concepts ? Norois 2011, 11-24. [CrossRef]

29. Sanyé-Mengual, E.; Orsini, F.; Gianquinto, G. Revisiting the Sustainability Concept of Urban Food Production from a Stakeholders' Perspective. Sustainability 2018, 10, 2175. [CrossRef]

30. FADEAR Agriculture Paysanne-Les Outils de L'agriculture Paysanne. Available online: http://www. agriculturepaysanne.org/les-outils-de-l-agriculture-paysanne (accessed on 11 May 2020).

31. Mok, H.-F.; Williamson, V.G.; Grove, J.R.; Burry, K.; Barker-Reid, F.; Hamilton, A.J. Strawberry fields forever? Urban agriculture in developed countries: A review. Agron. Sustain. Dev. 2013, 34, 21-43. [CrossRef]

32. Grimonprez, B. L'agriculture urbaine: Une agriculture juridiquement comme les autres? Revue De Droit Rural Editions Tech. Et Econ./LexisNexis. 2019, 12, 18, HAL Id: hal-02073564v2. 
33. Sanyé-Mengual, E.; Specht, K.; Grapsa, E.; Orsini, F.; Gianquinto, G. How Can Innovation in Urban Agriculture Contribute to Sustainability? A Characterization and Evaluation Study from Five Western European Cities. Sustainability 2019, 11, 4221. [CrossRef]

34. Veolia Institute Urban agriculture: Another way to feed cities; The Veolia Institute Review-Facts Reports; Veolia Institute: Aubervilliers, France, 2019; p. 128.

35. Aubry, C. Les fonctions alimentaires de l'agriculture urbaine au Nord et au Sud-Diversité et convergences. Bulletin de l'Association de géographes français 2013, 90, 303-317. [CrossRef]

36. Nugent, R. The impact of urban agriculture on the household and local economies. In Growing Cities, Growing Food: Urban Agriculture on the Policy Agenda. A Reader on Urban Agriculture; Deutsche Stiftung fur Internationale Entwicklung (DSE), Zentralstelle fur Ernahrung und Landwirtschaft: Feldafing, Germany, 2000; p. 32.

37. Dasylva, M.; Ndour, N.; Sambou, B.; Soulard, C.T. Les micro-exploitations agricoles de plantes aromatiques et médicinales: Élément marquant de l'agriculture urbaine à Ziguinchor, Sénégal. Cah. Agric. 2018, $27,25004$. [CrossRef]

38. Parrot, L.; Nantchouang, A.; Dongmo, C. The transformations of family farms in small cities: The case of Muea in Cameroon. Cah. Agric. 2015, 24, 215-223. [CrossRef]

39. Winkler, B.; Maier, A.; Lewandowski, I. Urban Gardening in Germany: Cultivating a Sustainable Lifestyle for the Societal Transition to a Bioeconomy. Sustainability 2019, 11, 801. [CrossRef]

40. Schram-Bijkerk, D.; Otte, P.; Dirven, L.; Breure, A.M. Indicators to support healthy urban gardening in urban management. Sci. Total. Environ. 2018, 621, 863-871. [CrossRef]

41. Audate, P.P.; Fernandez, M.A.; Cloutier, G.; Lebel, A. Scoping review of the impacts of urban agriculture on the determinants of health. BMC Public Health 2019, 19, 672. [CrossRef]

(C) 2020 by the authors. Licensee MDPI, Basel, Switzerland. This article is an open access article distributed under the terms and conditions of the Creative Commons Attribution (CC BY) license (http://creativecommons.org/licenses/by/4.0/). 